\title{
Ayo Sinau Basa Jawa: Bahan Digital Penunjang Pembelajaran Kosakata Bahasa Jawa Berbasis Multimedia
}

\author{
Ella Rizky Endryanti ${ }^{1}$, Roekhan $^{2}$, Primardiana Hermilia Wijayati ${ }^{3}$ \\ ${ }^{1}$ Keguruan Bahasa-Universitas Negeri Malang \\ ${ }^{2}$ Pendidikan Bahasa dan Sastra Indonesia-Universitas Negeri Malang \\ ${ }^{3}$ Pendidikan Bahasa dan Sastra Jerman-Universitas Negeri Malang
}

INFO ARTIKEL
Riwayat Artikel:
Diterima: 26-07-2019
Disetujui: 11-03-2020
Kata kunci:
digital materials;
javanese language vocabulary;
primary school;
bahan digital;
kosakata bahasa jawa;
sekolah dasar

\section{Alamat Korespondensi:}

Ella Rizky Endryanti

Keguruan Bahasa

Universitas Negeri Malang

Jalan Semarang 5 Malang

E-mail: ella.rizky11@gmail.com

\begin{abstract}
ABSTRAK
Abstract: This research aims to develop digital interactive teaching materials entitled "Ayo Sinau Basa Jawa" (Let's Learn Javanese) for students in grade I in elementary school. The research and development method used is ADDIE. The measures taken in this development research are analysis, design, development, implementation, dan Evaluation. The digital teaching method named Ayo Sinau Basa Jawa is a multimedia based interactive teaching material which provides menu called sinau (learn) and gladhen (practice) inside. The "sinau" material is presented by integrating pictures, sounds, and videos while "gladhen" is given in a form of quizzes. Products developed were validated by three experts according to the aspects assessed, namely aspects of content, language and multimedia. The content validation results obtained a score of $96 \%$, the results of language validation obtained a score of $93 \%$, and the results of multimedia validation scored $93 \%$. The result of this study is that the product is valid, so it is capable of being utilized and is attractive and effective to be used by elementary school students.

Abstrak: Penelitian ini bertujuan mengembangkan bahan ajar interaktif berupa bahan digital Ayo Sinau Basa Jawa bagi siswa kelas I Sekolah Dasar. Metode penelitian dan pengembangan yang digunakan adalah model ADDIE (Analysis, Design, Development, Implementation, Evaluation). Bahan digital Ayo Sinau Basa Jawa merupakan bahan ajar interaktif berbasis mulimedia yang menyediakan menu sinau (belajar) dan gladhen (latihan) didalamnya. Materi sinau disajikan dengan mengintegrasikan media gambar, audio dan video, sedangkan gladhen disajikan dalam bentuk kuis. Produk yang dikembangkan divalidasi oleh tiga ahli sesuai aspek yang dinilai, yakni aspek isi, bahasa, dan multimedia. Hasil validasi isi memperoleh skor $96 \%$, hasil validasi bahasa memperoleh skor 93\%, dan hasil validasi multimedia memperoleh skor 93\%. Hasil penelitian ini menunjukkan bahwa produk telah valid sehingga layak dan efektif digunakan oleh siswa Sekolah Dasar.
\end{abstract}

Eksistensi bahasa daerah di berbagai wilayah secara umum berada pada kondisi yang menurun. Terlebih di era perkembangan teknologi yang semakin canggih, turut memengaruhi perkembangan pembelajaran bahasa daerah dalam dunia pendidikan. Kota Malang merupakan salah satu daerah yang mengajarkan bahasa daerah yakni bahasa Jawa. Bahasa Jawa merupakan bahasa daerah yang digunakan penutur bersuku Jawa. Bahasa Jawa merupakan bahasa daerah yang menjadi bahasa komunikasi utama orang berbahasa ibu bahasa Jawa (Marsono, 2011). Penutur bahasa Jawa tersebar di daerah Provinsi Daerah Istimewa Yogyakarta, Jawa Tengah, Jawa Timur, Banten, Lampung, daerah sekitar Medan, serta daerah-daerah transmigrasi. Meskipun penutur bahasa Jawa tersebar di berbagai daerah, namun tidak berbanding lurus Bahasa Jawa memiliki tingkat tutur dalam penggunaan kosakatanya (Wedhawati dkk, 2016). Tingkat tutur merupakan variasi bahasa yang perbedaannya ditentukan oleh sikap pembicara kepada mitra bicara atau orang ketiga yang dibicarakan. Bahasa Jawa merupakan identitas orang Jawa yang menjunjung tata krama dalam bertutur. Selain itu, bahasa Jawa juga menjadi simbol keluhuran kebudayaan Jawa.

Dewasa ini banyak dikeluhkan atas anggapan siswa yang merasa pembelajaran bahasa Jawa menjadi salah satu mata pelajaran yang tidak menarik hingga sering kali dianggap menjadi mata pelajaran yang sulit. Di lapangan ditemui bahwa sumber ajar yang digunakan berupa buku ajar. Bahan ajar merupakan seperangkat bahan yang memuat materi atau isi pembelajaran yang didesain untuk mencapai tujuan pembelajaran (Sungkono, 2003). Buku ajar yang digunakan merupakan 
hasil penyusunan oleh tim KKG Kota Malang dalam payung kurikulum yang ada pada Peraturan Gubernur Jawa Timur No 19 Tahun 2019. Menurut penuturan guru pengajar bahasa Jawa, buku tersebut telah sesuai dengan aturan bahwa pembelajaran bahasa Jawa mengacu pada kearifan lokal masing-masing daerah. Kesulitan siswa dalam memahami pembelajaran bahasa Jawa yang disebabkan oleh beberapa faktor, perlu mendapat perhatian lebih. Faktor-faktor tersebut di antaranya, kosakata dalam bahasa Jawa yang tidak sering didengar siswa dalam kegiatan sehari-hari sebab menggunakan dialek Solo-Yogya. Hal tersebut berbeda dengan kondisi kebahasaan siswa sehari-hari yang cenderung menggunakan bahasa Jawa dialek Malang.

Pada penelitian sebelumnya, Utari (2012) menjelaskan bahwa faktor yang mendominasi siswa kurang berminat terhadap pembelajaran bahasa Jawa terletak pada perbedaan kosakata bahasa Jawa yang dipelajari siswa di sekolah dengan kosakata bahasa Jawa yang digunakan dalam kehidupan sehari-hari (Utari, 2012). Hal tersebut membuat siswa menjadi kurang memiliki kemampuan dalam memahami kosakata bahasa Jawa yang dipelajari di sekolah sehingga mereka cenderung menggunakan kosakata yang diketahui sebelumnya. Widodo dalam hasil penelitiannya menjelaskan pula bahwa kesulitan anakanak sekolah dasar mempelajari bahasa Jawa pada kosakata (Widodo dkk, 2017). Siswa SD kesulitan dalam mempelajari kosakata bahasa Jawa dikarenakan bahasa Jawa memiliki istilah-istilah khusus dan bermakna sama. Selain itu, dikarenakan pula perbedaan penggunaan kosakata bahasa Jawa yang bergantung lawan bicara.

Pada kegiatan Kongres Bahasa Jawa VI, Pranowo menjelaskan hasil penelitianya bahwa terjadi kemerosotan motivasi siswa dalam belajar bahasa Jawa. Faktor merosotnya motivasi siswa terhadap pembelajaran bahasa Jawa terjadi karena (1) banyak pengajar Bahasa Jawa tidak memiliki kompetensi berbahasa Jawa secara memadai, (2) jumlah jam pelajaran bahasa Jawa terbatas, (3) kedudukan bahasa Jawa hanya sebagai muatan lokal sehingga kurang memotivasi anak, (4) jumlah undha usuk bahasa Jawa yang banyak dan menyulitkan anak didik, (5) lingkungan keluarga dan masyarakat kurang mendukung penguasaan bahasa Jawa, (6) kemahiran berbahasa Jawa tidak menjanjikan nilai ekonomi yang memadai, dan (7) adanya anggapan masyarakat bahwa dengan berbahasa Indonesia sejak di lingkungan keluarga akan membantu anak dalam mengikuti pelajaran di sekolah (Pranowo, 2016). Kondisi yang demikian membuat pembelajaran bahasa Jawa semakin ditinggalkan oleh siswa.

Kondisi lain yang ditemui di lapangan, banyak keluarga muda yang tidak menggunakan bahasa Jawa menjadi bahasa ibu atau bahasa pertama dalam berkomunikasi dengan anak. Tingkat tutur bahasa Jawa memiliki tingkatan kesantunan yang perlu dipahami oleh siswa. Pemahaman tersebut perlu ditanamkan sejak siswa berada dalam masa golden age, agar tersimpan dalam memori dan digunakan dengan benar. Peran keluarga terlebih orangtua mendapat posisi penting dalam perkembangan penguasaan bahasa anak, tetapi berbanding terbalik dengan kondisi di lapangan. Observasi peneliti yang dilakukan di lapangan menghasilkan kondisi bahwa sebagian besar siswa kurang memahami beberapa kosakata atau istilah Jawa yang ditemui dalam pembelajaran. Kesulitan siswa terdapat pada pemahaman kosakata bahasa Jawa yang dialeknya berbeda dengan dialek keseharian mereka. Sebagian besar siswa juga merasa sulit saat menggunakan tingkat tutur krama. Hal tersebut membuat waktu pembelajaran yang dilakukan di sekolah kurang untuk memahami kosakata bahasa Jawa dengan cepat. Dengan kondisi demikian, sumber ajar yang berintegrasi dengan teknologi untuk menyesuaikan kondisi anak-anak di era perkembangan teknologi seperti ini perlu dilakukan.

Penelitian terdahulu mengenai pengembangan berbasis muatan lokal pernah dilakukan oleh Segoro dkk, tentang Buku Ajar Tematik Berbasis Muatan Lokal untuk Kelas IV Sekolah Dasar. Penelitian dan pengembangan yang dilakukan tersebut menghasilkan bahan ajar tematik berbasis muatan lokal di Kabupaten Tulungagung tema pahlawanku dengan mengembangkan tokoh sejarah lokal yakni Raden Mas Djajeng Koesoemo (Segoro \& Sapto, 2019). Hal tersebut bertujuan bahan ajar lebih dekat dengan kearifan lokal siswa di Tulungagung. Penelitian lain juga dilakukan oleh Mulyani tentang Pengembangan Model Bahan Ajar Berbasis Potensi Daerah untuk Menunjang Pembelajaran Bahasa Jawa. Penelitian dan pengembangan tersebut mengembangkan potensi daerah berupa istilah-istilah peralatan dapur di Yogyakarta. Hasil penelitian dan pengembangan tersebut berupa bahan ajar yang memuat piranti dapur di wilayah setempat. Hal tersebut dilakukan agar bahan ajar sesuai dengan kearifan lokal wilayah Yogykarta (Mulyani, 2013). Penelitian dan pengembangan berbasis muatan lokal di daerah lain juga dilakukan oleh Anwar dengan judul Pengembangan Modul Pembelajaran Tematik Terpadu Berbasis Kearifan Lokal Kabupaten Sumenep Kelas IV Subtema Lingkungan Tempat Tinggalku. Hasil penelitian dan pengembangan tersebut berupa bahan ajar yang berisi tentang cerita fiksi dan nonfiksi daerah-daerah di Sumenep (Anwar, Ruminiati, Suharjo, 2017). Berkaitan dengan sumber ajar berbasis muatan lokal daerah, maka kota Malang memiliki kearifan lokal yang perlu dikembangkan. Namun, di era saat ini, selain bahan ajar merujuk pada kearifan lokal daerah masing-masing perlu juga ditambahkan dengan pengintegrasian teknologi. Pengintegrasian teknologi sebagai sarana penyeimbang keseharian siswa yang tidak jauh dengan teknlogi. Bahan ajar interaktif menjadi alternatif yang cocok di era saat ini.

Prastowo menjelaskan bahwa bahan ajar interaktif merupakan bahan ajar yang mengombinasikan berbagai media pembelajaran (audio, video, grafik, dll) yang bersifat interaktif untuk mengendalikan suatu perintah dari suatu presentasi atau sajian (Prastowo, 2016). Bahan ajar interaktif menjadi bahan ajar yang menjadikan siswa aktif, sebab terjadi interaksi dua arah. Penggunaan bahan ajar interaktif berarti melaksanakan pembelajaran berbasis multimedia untuk memposisikan siswa agar mendapat pengalaman langsung sehingga menjadi stimulus bagi siswa (Smaldino, 2011). Pembelajaran melibatkan perangkat yang berbasis multimedia membuat siswa merasakan pengalaman nyata melalui proses akuisisi dari visual yang didapatkan dalam bahan berbasis multimedia. Penggunaan bahan ajar berbasis teknologi, khususnya berbasis multimedia membuat siswa tidak hanya mendengar dan melihat sajian, namun mereka dapat merespons aktif terhadap sajian yang tersedia. Hal ini sejalan 
dengan pendapat Kapi yang menjelaskan bahwa pembelajaran menggunakan perangkat multimedia dapat memberikan stimulus siswa untuk aktif mengikuti pembelajaran (Kapi, Osman, Ramli, \& Taib, 2017). Penelitian sebelumnya yang berkenaan dengan penggunaan bahan ajar atau media interaktif pernah dilakukan oleh Wulandari dkk, dengan judul Penggunaan Multimedia Interaktif Bermuatan Game Edukasi untuk Meningkatkan Aktivitas dan Hasil Belajar Siswa Sekolah Dasar. Hasil penelitian tersebut berhasil meningkatkan hasil belajar siswa melalui multimedia interaktif yang sesuai dengan siswa (Wulandari, Susilo, \& Kuswandi, 2017).

Penelitian dan pengembangan berkatian dengan multimedia interaktif juga dilakukan oleh Marsuki tentang Peningkatan Karakter Siswa melalui Pengembangan Buku Ajar bahasa Inggris Interaktif Berbasis Nilai-Nilai Budaya Bangsa. Hasil penelitian dan pengembangan tersebut berhasil mewujudkan bahan ajar bahasa Inggris interaktif yang integratif dan efektif digunakan untuk siswa (Marsuki \& Efendy, 2015). Oleh karena itu, pengembangan ini mengembangkan bahan ajar sesuai dengan kearifan lokal kota Malang yang berbasis multimedia.

\section{METODE}

Model pengembangan yang digunakan untuk bahan digital Ayo Sinau Basa Jawa yakni model pengembangan ADDIE. Langkah-langkah penelitian dan pengembangan model ADDIE, terdiri atas (1) Analysis, (2) Design, (3) Development, (4) Implementation, dan (5) Evaluation (Nada Aldoobie, 2015). Analisis kebutuhan dilakukan dengan cara mengidentifikasi masalah-masalah yang terjadi di lapangan, menganalisis bahan ajar yang telah digunakan siswa, melakukan observasi pembelajaran bahasa Jawa di kelas dan mengidentifikasi hasil wawancara dengan guru bahasa Jawa di SD. Tahap desain ialah proses desain untuk menentukan tujuan pembuatan bahan ajar, menentukan materi yang dikembangkan, dan menentukan spesifikasi produk. Tahap pengembangan berisi kegiatan proses mewujudkan storyboard menjadi bentuk nyata. Pada tahap ini produk dikembangkan dan dikerjakan sampai dihasilkan produk jadi berupa bahan digital penunjang pembelajaran kosakata bahasa Jawa berbasis multimedia yang berjudul Ayo Sinau Basa Jawa. Tahap implementasi merupakan tahapan mencoba produk berupa validasi yang dilakukan ahli dan ujicoba oleh siswa di lapangan. Tahap terakhir pada pengembangan ialah tahap evaluasi. Tujuan tahap evaluasi untuk menilai kualitas produk dan keefektifan produk dalam proses pembelajaran di kelas.

Uji coba produk dilakukan sebanyak dua tahap, yakni uji validasi dan uji pemakaian. Uji validasi dilakukan sebanyak tiga kali sesuai aspek yang dinilai dan divalidasi masing-masing aspek oleh seorang validator. Ketiga validator tersebut ialah ahli isi dalam bidang bahan ajar, ahli bahasa Jawa dan ahli multimedia. Uji pemakaian dilakukan sebanyak dua tahap, yakni uji pemakaian kelompok kecil dan kelompok besar. Uji coba dilakukan di SDK Marga Bhakti Kota Malang dengan sasaran siswa kelas I. Jenis data yang diperoleh dari penelitian dan pengembangan bahan digital Ayo Sinau Basa Jawa ini berupa data kuantitatif dan kualitatif. Data kuantitatif diperoleh dari hasil perhitungan angket yang diberikan kepada responden menggunakan skala likert. Data kualitatif didapat dari validator yang memberikan data berupa kritik dan saran tentang produk yang dikembangkan. Instrumen pengumpulan data yang digunakan dalam penelitian dan pengembangan ini, meliputi angket, tes, dan wawancara. Data penilaian yang diperoleh dari ahli isi/materi, ahli bahasa, dan ahli multimedia dipaparkan sesuai hasil yang diperoleh. Data penilaian angket kemenarikan, kepraktisan, dan hasil keefektifan produk dipaparkan menggunakan teknik persentase.

\section{HASIL}

Bahan digital Ayo Sinau Basa Jawa merupakan bahan digital penunjang pembelajaran bahasa Jawa untuk siswa kelas I Sekolah Dasar. Bahan digital ini berbasis multimedia sehingga hasil produk yang dikembangkan merupakan bahan ajar interaktif. Bahan digital Ayo Sinau Basa Jawa mengintegrasikan media gambar, teks, audio dan video. Produk tersebut dikembangkan menggunakan software unity 3D. Berikut ini gambar sampul bahan digital yang dikembangkan (Gambar 1, 2, 3, dan 4).

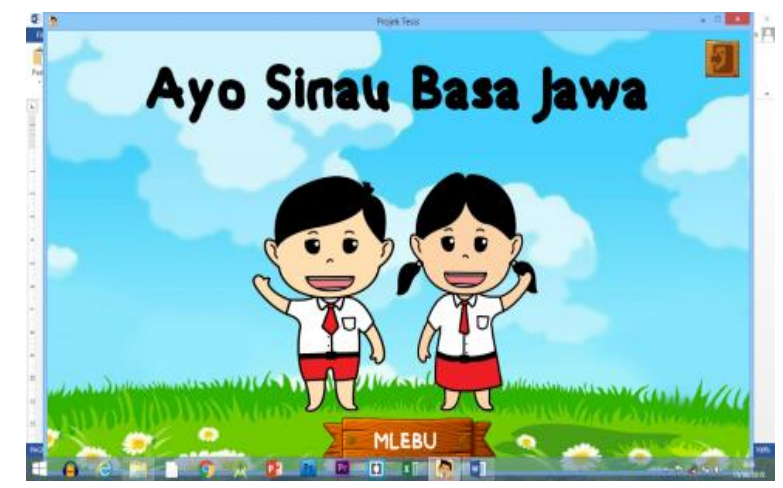

Gambar 1. Sampul Bahan Digital Ayo Sinau Basa Jawa 
Skema bahan digital Ayo Sinau Basa Jawa dimulai dengan tombol play untuk menjalankan produk, kemudian tayangan tujuan bahan digital, kemudian masuk pada tayangan intro produk, dan masuk pada halaman sampul produk dengan ditandai adanya tombol mlebu untuk masuk pada tampilan pilihan menu utama produk. Pada tampilan pilihan menu utama terdapat beberapa pilihan tombol di antaranya, materi (penjabaran materi), carane nggawe (petunjuk penggunaan), pengrakit (identitas penyusun), sinau (pilihan tema yang akan dipelajari), gladhen (pilihan latihan soal), dan metu (keluar).

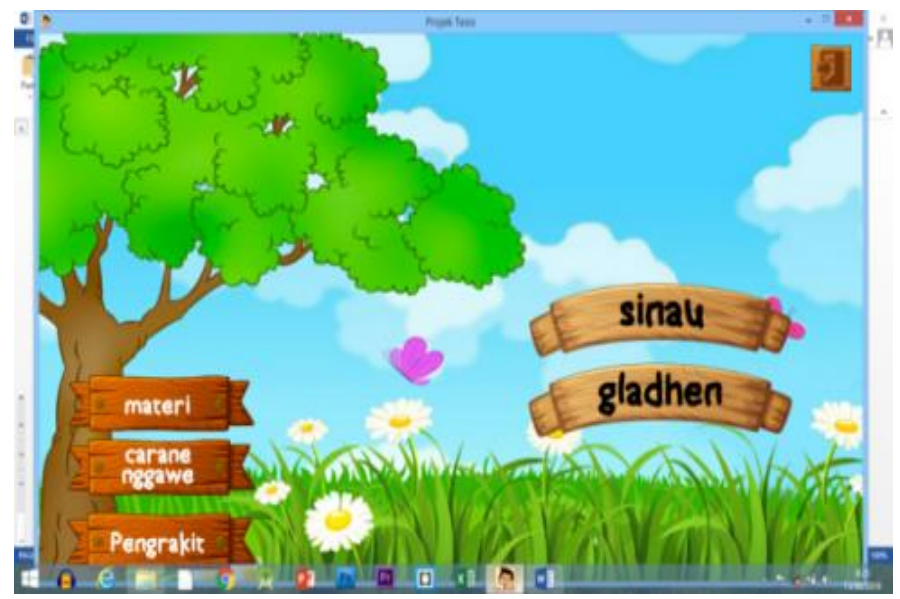

Gambar 2. Tampilan Menu Utama Produk

Materi yang dikembangkan dalam bahan digital Ayo Sinau Basa Jawa yakni materi kelas I semester I yang terdiri atas empat tema. Tema-tema tersebut di antaranya, tema I Awakku (Diri Sendiri), tema II Kasenenganku (Kegemaranku), tema III Kagiyatanku (Kegiatanku), dan tema IV Kulawargaku (Keluargaku) yang disusun dengan pendekatan tematik. Latihan soal dalam bahan digital terdiri atas empat tingkatan, yakni gladhen 1, gladhen 2, gladhen 3, dan gladhen 4. Bahasa yang dikembangkan dalam bahan digital Ayo Sinau Basa Jawa menggunakan bahasa Jawa, Jawa Timuran. Bahasa yang digunakan dalam sajian materi terdiri atasa bahasa Jawa ngoko dialek Malang dan bahasa Jawa krama. Bahasa yang digunakan dalam pengantar materi atau kalimat-kalimat perintah pada produk menggunakan bahasa Jawa ngoko dialek Malang.

Kosakata yang disajikan dalam bahan digital Ayo Sinau Basa Jawa merupakan kosakata dasar, baik dalam tingkat tutur ngoko maupun krama. Kosakata dasar yang disajikan meliputi, nama-nama bagian tubuh, kata bilangan, kata kerja, kata keadaan, kata keterangan, dan istilah kekerabatan. Kosakata bahasa Jawa dipilih dengan kriteria kosakata yang dapat dirasa dan digunakan anak-anak dalam sehari-hari. Tampilan gambar dalam produk Ayo Sinau Basa Jawa diproses melalui pembuatan dan pemilihan karakter yang sesuai dengan usia sasaran. Tokoh-tokoh tersebut menggambarkan anak sekolah, guru, teman-teman sebaya, bapak, ibu, paman, bibi, nenek, dan kakek.

Penggunaan bahan digital penunjang Ayo Sinau Basa Jawa dilengkapi dengan buku petunjuk guru dan jurnal belajar siswa. Buku petunjuk guru digunakan sebaai panduan menjalankan program. Buku jurnal belajar siswa buku sinauku, digunakan siswa untuk menuliskan hal-hal yang telah didapat dari pembelajaran bahan digital Ayo Sinau Basa Jawa. Bentuk buku petunjuka dapat dilihat pada gambar 3. Buku jurnal belajar siswa juga sebagai jembatan guru untuk mengecek siswa dalam memahami kosakata bahasa Jawa. Bentuk buku jurnal belajar siswa dapat dilihat dalam gambar 4.

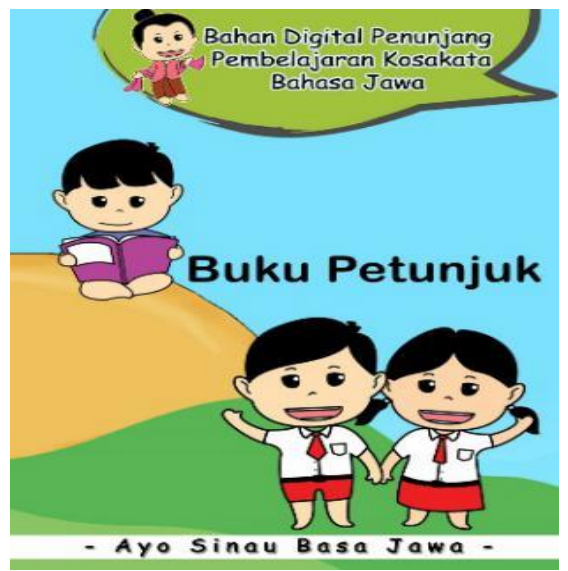

Gambar 3. Buku Petunjuk

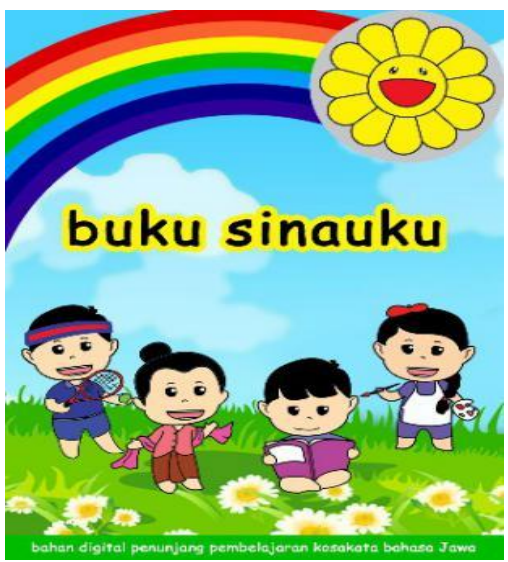

Gambar 4. Jurnal Belajar Siswa 
Hasil validasi produk bahan digital Ayo Sinau Basa Jawa dari ketiga ahli diperoleh skor sebesar 94\%, dapat disimpulkan bahwa bahan digital Ayo Sinau Basa Jawa dinyatakan valid. Kemenarikan bahan digital ayo Sinau Basa Jawa memperoleh skor sebesar 96,5\%, yang termasuk dalam kriteria sangat menarik. Kepraktisan bahan digital Ayo Sinau Basa Jawa memperoleh skor sebesar $87 \%$, yang termasuk dalam kriteria praktis. Keefektifan bahan digital yang dikembangkan ditunjukkan dengan adanya peningkatan nilai rata-rata belajar siswa dari pretest dan postest, sebesar 55,3 menjadi 80. Dengan demikian menunjukkan bahan digital Aуo Sinau Basa Jawa dapat digunakan sebagai bahan digital penunjang pembelajaran kosakata bahasa Jawa.

\section{PEMBAHASAN}

Pembahasan hasil produk bahan digital Ayo Sinau Basa Jawa terdiri atas tiga aspek, yakni aspek isi, aspek bahasa, dan aspek tampilan.

\section{Aspek Isi}

Materi yang dikembangkan dalam bahan digital Ayo Sinau Basa Jawa ialah materi semester I yang terdiri atas empat tema. Tema-tema tersebut di antaranya tema I Awakku, tema II Kasenenganku, tema III Kagiyatanku, dan tema IV Kulawargaku. Isi materi dalam setiap tema dikembangkan sesuai dengan kebutuhan dan karakteristik siswa. Pengembangan secara tematik dilakukan karena relevan dengan kebutuhan perkembangan siswa yang perlu mengembangkan diri dalam ranah kognitif, afektif, dan psikomotorik (Prastowo, 2014). Bahan digital Ayo Sinau Basa Jawa dikembangkan untuk siswa sekolah dasar kelas I, sebab sejak usia dini perlu menanamkan pemahaman kosakata yang benar terhadap pembelajaran bahasa Jawa. Sesuai teori yang dikemukakan Piaget dalam Papalia yang menjelaskan usia anak pada angka tujuh tahun merupakan usia anak memasuki operasional konkret (Papalia \& Diane E, 2010). Anak mulai dapat berpikir dengan logis dan mampu mengategorisasi hal-hal yang sederhana menuju kompleks. Hal tersebut yang melatar belakangi pengembangan yang dilakukan perlu dimulia pada usia siswa kelas I SD dengan pendekatan tematik.

Pembelajaran tematik yang dekat dengan realitas kehidupan siswa akan membantu mempermudah pemahaman siswa terhadap pembelajaran bahasa Jawa. Sejalan dengan pendapat Prastowo yang menjelaskan bahwa karakteristik sumber belajar tematik adalah aktif, menyenangkan, holistik, dan autentik (Prastowo, 2016). Bahan digital yang dikembangkan kali ini juga mengintregasikan beberapa media untuk menunjang bahan digital yang interaktif. Materi yang dikembangkan dalam bahan digital penunjang pembelajaran bahasa Jawa ini disesuaikan dengan kearifan lokal kota Malang. Isi materi dan kosakata dalam produk dikembangkan dengan memilih kosakata yang komunikatif. Hal ini sesuai dengan salah satu tujuan kurikulum bahasa daerah dalam peraturan Gubernur Jawa Timur bahwa kurikulum muatan lokal bertujuan untuk mengarahkan siswa mampu berkomunikasi secara efektif dan efisien sesuai tingkat tutur atau etika yang tepat (Pergub, 2014).

Topik-topik yang dipilih dan dikembangkan sesuai dengan keseharian siswa di Malang, sehingga topik mudah dipahami dan siswa dapat belajar kosakata-kosakata baru dalam pembelajaran bahasa Jawa di kelas. Pemberian topik-topik yang dekat dengan keseharian sesuai dengan kondisi psikologi perkembangan anak pada usia SD (7-11tahun). Hal tersebut seperti dijelaskan oleh Rusman bahwa anak usia 7-11 tahun berada pada tahap operasional yang konkret. Kecenderungan karakteristik belajar anak pada usia tersebut yang menonjol ialah konkret, integratif, dan hierarkis (Rusman, 2011). Konkret yang dimaksudkan ialah proses belajar siswa bermula dari hal-hal yang konkret dengan titike penekanan lingkungan sekitar sebagai sumber belajar pertama. Integratif yang dimaksudkan ialah memandang sesuatu sebagai kesatuan yang utuh dan terpadu, keterpaduan bukan berarti dipilah-pilah menjadi berbagai disiplin ilmu, namun dikaitkan menjadi pengalaman belajar yang bermakna (meaningful learning). Pembelajaran bermakna didukung dengan sumber ajar yang berkaitan dengan pengalaman dan perkembangan psikologis siswa. Pembelajaran dengan kebermaknaan tinggi ialah apabila siswa mengalami dengan berbuat dan terlibat (Akbar, 2017). Isi bahan digital yang dikembangkan mengarahkan siswa untuk mengalami atau melakukan suatu hal menirukan contoh pada tayangan bahan digital.

\section{Aspek Bahasa}

Bahan digital Ayo Sinau Basa Jawa selain menggunakan kosakata-kosakata dialek Malang sebagai ciri khasnya, materi tematik dikembangkan sesuai dengan kondisi dan karakter siswa di kota Malang. Bahasa Jawa dialek standar merupakan bahasa Jawa yang digunakan di daerah Yogyakarta dan Solo, sedangkan dialek Jawa Timur merupakan dialek bahasa Jawa yang digunakan di hampir seluruh Propinsi Jawa Timur (Wedhawati dkk, 2016). Kekahasan dialek terletak pada tata bunyi atau sistem fonetik pada kedua dialek. Penggunaan dialek Jawa Timur khususnya Malang, sesuai dalam Peraturan Gubernur Jawa Timur No 19 Tahun 2014 pada pasal 4 yang mengatur tentang materi ajar bahasa daerah. Dalam peraturan (Pergub, 2014) disebutkan bahwa materi ajar bahasa Jawa seyogyanya bersumber dari budaya, tata nilai dan perkembangan masyarakat sesuai kearifan lokal masing-masing daerah. Selain itu, dalam pasal tersebut juga menyebutkan bahwa seyogyanya materi ajar bahasa Jawa dipilih dan ditekankan pada hal komunikatif, rekreatif, dan pragmatik sehingga berdaya guna bagi siswa dalam kehidupan di lingkungannya. 
Bahan digital Ayo Sinau Basa Jawa menggunakan kosakata dialek Malang pada tataran ngoko memiliki tujuan bahwa dialek Malang sebagai kearifan lokal Malang. Dengan demikian siswa mudah memahami kosakata sehari-hari yang mereka jumpai sehinggga siswa dapat tertarik dan termotivasi mempelajari kosakata bahasa Jawa dalam tataran krama. Oleh karena itu, bahan digital Ayo Sinau Basa Jawa menggunakan tingkat tutur ngoko dengan dialek Malang dan tingkat tutur krama agar siswa dapat menangkap pembelajaran dengan mudah. Apabila siswa dapat dengan mudah memahami pembelajaran, maka siswa akan dapat menerapkan menggunakan kosakata bahasa Jawa dengan tingkat tutur yang benar.

Kosakata bahasa Jawa yang dikembangkan dalam produk bahan digital Ayo Sinau Basa Jawa bagi siswa kelas I Sekolah Dasar merupakan kosakata dasar. Tarigan (2015) menjelaskan bahwa kosakata dasar merupakan kata-kata yang tidak mudah berubah atau sedikit kemungkinan dipungut dari bahasa lain (Tarigan, 2015). Berikut yang termasuk pada kosakata dasar, di antaranya istilah kekerabatan, nama-nama bagian tubuh, kata ganti, kata bilangan pokok, kata kerja pokok, kata keadaan pokok dan benda-benda universal. Hal ini menyesuaikan usia belajar siswa dan pencapaian belajar siswa. Kosakatakosakata dasar yang diberikan berada pada tataran ngoko dan krama. Kosakata pada tataran krama dikembangkan dalam produk, jumlahnya tidak sebanyak kosakata ngoko yang dikembangkan sebab sebagai stimulus penggunaan kosakata krama. Namun, penempatan kosakata krama diletakkan pada posisi yang seharusnya untuk membiasakan para siswa menggunakan kosakata krama dengan tepat.

\section{Aspek Tampilan}

Sajian materi pada tiap-tiap tema terintregasi atas beberapa media, yakni media teks, gambar, audio, dan video. Latihan soal disajikan dengan bentuk kuis dengan model mencocokkan gambar, mencocokkan kata dan mengisi kata. Mediamedia tersebut disusun dengan menarik dan dapat diputar ulang sesuai kebutuhan pembelajaran. Penggunaan materi yang dapat diulang yang disertai audio dan beberapa melalui nyanyian merupakan ciri khas produk ini. Hal ini sejalan dengan Papalia menjelaskan strategi pengungalan dalam belajar yang dibuat sengaja pada anak. Dijelaskan bahwa pada usia anak 6-7 tahun banyak ahli yang menyarankan strategi pembelajaran dengan pengulangan yang disengaja, sebab di usia tersebut siswa dapat melakukaknnya dengan spontan (Papalia \& Diane, 2010). Bahan digital Ayo Sinau Basa Jawa menggunakan nyanyian dan sajian teks yang disertai audio agar proses pengulangan ini dapat terjadi dan memberikan pengaruh yang baik pada proses pembelajaran bahasa Jawa di sekolah.

Sajian materi dan latihan terintregasi atas beberapa media agar siswa dapat terlibat aktif dalam pembelajaran sehingga timbul rasa senang saat belajar. Pengintregasian beberapa media juga dilakukan untuk mewadahi gaya belajar siswa di era saat ini. Dalam gaya belajar siswa saat ini, terdapat tiga gaya belajar, yakni visual, auditori, dan kinestetik (Tung, 2015). Gaya belajar visual merupakan gaya belajar siswa yang cenderung memahami pembelajaran melalui melihat tampilan visual, membaca, ekspresi, dan bahasa tubuh. Gaya belajar auditori merupakan gaya belajar siswa yang cenderung memahami pembelajaran melalui mendengarkan guru, berbicara, berdiskusi ataupun mendengarkan ceramah, sedangkan gaya belajar kinestetik merupakan gaya belajar siswa yang cenderung memahami pembelajaran dengan turut melakukan gerakan dan ikut mengerjakan suatu pekerjaan. Dengan demikian, pengintregasian beberapa media dalam bahan digital Ayo Sinau Basa Jawa dapat dijadikan alternatif bahan pembelajaran yang dibutuhkan siswa.

Kemudahan navigasi merupakan rancangan navigasi yang komunikatif dan mudah dipahami sehingga mudah digunakan, hal ini telah sesuai dengan rancangan navigasi dalam produk. Kandungan kognisi, materi dalam bahan digital Ayo Sinau Basa Jawa telah memberikan pengalaman kognitif (pengetahuan) yang dibutuhkan siswa. Selanjutnya, integrasi media, bahan digital Ayo Sinau Basa Jawa telah terintegrasi dengan media teks, gambar, audio, dan video. Media-media yang telah terintegrasi tersebut diharap mampu memberikan pengalaman pengetahuan dan kemampuan eksplorasi siswa terhadap kosakata bahasa Jawa sehingga siswa mampu berbicara dengan aktif dan benar dalam tingkat tutur bahasa Jawa. Kriteria selanjutnya ialah menarik dan artistik, hal tersebut dinyatakan dalam angket kemenarikan siswa dan guru dengan hasil bahan digital Ayo Sinau Basa Jawa dinyatakan sangat menarik. Kriteria yang terakhir ialah fungsi secara keseluruhan. Hal ini berarti produk yang dikembangkan harus memberikan pembelajaran yang diinginkan siswa secara utuh. Bahan digital Ayo Sinau Basa Jawa telah menyajikan kesatuan pembelajaran dengan sajian materi yang menarik dan latihan soal berbentuk kuis, sehingga siswa merasa seperti bermain game saat mengerjakan soal.

\section{SIMPULAN}

Proses penelitian dan pengembangan yang dilakukan menghasilkan bahan digital Ayo Sinau Basa Jawa. Bahan digital Ayo Sinau Basa Jawa merupakan bahan penunjang pembelajaran kosakata bahasa Jawa bagi siswa kelas I SD di Kota Malang. Bahan digital yang dikembangkan telah sesuai dengan kearifan lokal Malang dan kurikulum pembelajaran bahasa Jawa sebagai muatan lokal dalam Pergub Jatim No 19 Tahun 2014. Produk bahan digital Ayo Sinau Basa Jawa telah melalui proses validasi dan proses uji sesuai tahapan, sehingga produk ini dinyatakan layak digunakan dalam proses pembelajaran. Bahan digital Ayo Sinau Basa Jawa dapat digunakan sebagai bahan penunjang pembelajaran, bahan pemantik kreativitas siswa, dan bahan pemicu pembelajaran yang aktif bagi siswa di kelas. Bagi pengembang selanjutnya, perlu banyak digali materi-materi pembelajaran bahasa Jawa di Jawa Timur sesuai kearifan lokal daerah masing-masing agar menginovasi pembelajaran bahasa Jawa baik dari segi bahasa, teknik, metode, dan teknologi. 


\section{DAFTAR RUJUKAN}

Akbar, S. (2017). Instrumen Perangkat Pembelajaran. Bandung: Remaja Rosdakarya.

Anwar, M. F. N., Ruminiati., \& Suharjo. (2017). Pengembangan Modul Pembelajaran Tematik Terpadu Berbasis Kearifan Lokal Kabupaten Sumenep Kelas IV Subtema Lingkungan Tempat Tinggalku. Jurnal Pendidikan: Teori, Penelitian, dan Pengembangan, 2(10), 1291-1297.

Kapi, A. Y., Osman, N., Ramli, R. Z., \& Taib, J. M. (2017). Multimedia Education Tools for Effective Teaching and Learning. $9(2), 4$.

Khoe Yao Tung. (2015). Pembelajaran dan Perkembangan Belajar. Jakarta: Indeks.

Marsono. (2011). Morfologi Bahasa Indonesia dan Bahasa Nusantara. Yogyakarta: Gadjah Mada Press.

Marsuki, M., \& Efendy, B. A. (2015). Peningkatan Karakter Siswa melalui Pengembangan Buku Ajar Bahasa Inggris Interaktif Berbasis Nilai-Nilai Budaya Bangsa. Lingua: Jurnal Ilmu Bahasa dan Sastra, 10(1), 9-17. https://doi.org/10.18860/ling.v10i1.3028

Mulyani, S., Widyastuti, S. H., \& Hendri, Z. (2013). Pengembangan Model Bahan Ajar Berbasis Potensi Daerah untuk Menunjang Pembelajaran Bahasa Jawa. Jurnal Kependidikan: Penelitian Inovasi Pembelajaran, 43(1), 51-60.

Papalia., \& Diane, E. (2010). Human Development (Psikologi Perkembangan). Jakarta: Kencana.

Pergub. (2014). Peraturan Gubernur Jawa Timur Nomor 19 tentang Mata Pelajaran Bahasa Daerah sebagai Muatan Lokal Wajib di Sekolah/Madrasah. Diambil dari https://jdih.surabaya.go.id/pdfdoc/pergub_19.pdf

Pranowo. (2016). Rekayasa Pembelajaran Bahasa Jawa di Pendidikan Dasar. Prosiding Kongres Bahasa Jawa (KBJ) VI (BUKU 3) Bahasa Jawa Triwikrama Pengoptimalan Peran Bahasa dan Sastra Jawa di Kabupaten dan Kota yang Berakarkan Budaya Jawa untuk Memperkuat Kebudayaan Nasional, Yogyakarta, 8-12 November 2016.

Prastowo, A. (2014). Pemenuhan Kebutuhan Psikologis Peserta Didik SD/MI melalui Pembelajaran Tematik-Terpadu. Jurnal JPSD (Jurnal Pendidikan Sekolah Dasar), 1(1), 1-13.

Rusman. (2011). Model-Model Pembelajaran: Mengembangkan Profesionalisme Guru. Jakarta: Rajawali Press.

Segoro, B., \& Sapto, A. (2019). Buku Ajar Tematik Berbasis Muatan Lokal untuk Kelas IV Sekolah Dasar. 5.

Smaldino Sharon. (2011). Instructional Technology \& Media for Learning: Teknologi Pembelajaran dan Media untuk Belajar. Jakarta: Kencana Prenada Media Group.

Tarigan, H. G. (2015). Berbicara Sebagai Suatu Ketrampilan Berbahasa. Bandung: Angkasa.

Utari, N. R. D. (2012). Kemampuan Berbahasa Jawa pada Siswa Sekolah Dasar di SDN Tandes Kidul I/1 10 Surabaya. Skripsi tidak diterbitkan. Universitas Airlangga, Surabaya.

Wedhawati, dkk. (2016). Tata Bahasa Jawa Mutakhir. Yogyakarta: Kanisius.

Widodo dkk. (2017). Pembelajaran Bahasa Jawa di Sekolah Dasar. Seminar Nasional Hasil Penelitian (SNPH)-VII, Lembaga Peneltian dan Pengabdian Kepada Masyarakat Univeersitas PGRI Semarang.

Wulandari, R., Susilo, H., \& Kuswandi, D. (2017). Penggunaan Multimedia Interaktif Bermuatan Game Edukasi untuk Meningkatkan Aktivitas dan Hasil Belajar Siswa Sekolah Dasar. Jurnal Pendidikan: Teori, Penelitian, dan Pengembangan, 2(8), 1024-1029. 